\title{
Case Study of Tolled Road Project
}

\author{
Engineer Rinaj Pathan ${ }^{1} \&$ Prof. Dr. S. S. Pimplikar ${ }^{2}$ \\ (CivilDepartment, M.I.T.College of Engineering, PaudRoad, Pune 411038/University of Pune, India)
}

\begin{abstract}
To assess the risks involved in BOT PROJECT by studying a specific case of Implementation of integrated road development program me(IRDP) in the city on built, operate \& transport (BOT) basis. To Study the individualistic approach of the involved parties.

BOT has been one of the recent innovations in project finance. The Build-Operate-Transfer (BOT) scheme is a limited recourse financing technique. Many have adopted this approach as an alternative to traditional public financing for infrastructure development projects.

This study examines the type of SOCIAL risk due to, force shutdown of toll booths due to public riots. This paper mainly representing therisk inBOT due to political \& public pressure. A case study of IRDP project implemented in municipal corporation area through BOT is studied in detail.
\end{abstract}

Key Words: BOT, Irdp, Risk, MuncipalCorporation,State Road Development Corporation, Toll

\section{Introduction}

Many of the challenges involved in developing and financing road projects are similar to those faced by earlier infrastructure projects. The issues, which assume special importance in the case of toll road projects, however include risks associated with acquisition of long segments of right-of way, cost and time overruns in project implementation due to unforeseen weather conditions and more importantly, the market risks arising out of difficulties in forecasting traffic volumes and their sensitivity to toll rates. And of social risk due to, force shutdown of toll booths due to public riots

Such projects undergo significant change in their risk profile as they move from the pre-completion to the post- completion stage. While 'permitting risks' and risks associated with timely completion of the project dominate the pre- completion period, the primary risk in the post completion period pertains to the ability of the stretch to attract the necessary amount of traffic, and also for users to pay the requisite amount of tolls. But in this particular case study major risk involved is unwillingness to pay toll by the user.

\section{Project Background}

Xyz is a historical, culturally vibrant and politically important city in a representative state of India. The city is well known for temple, leather industry.Modernin house many education institutions, University, divisional or regional offices of Government/ private sector and Industrial development corporation industrial area. Sugar manufacturing units in co-op sector have increased the commercial activities in the city many fold.

As a result of increase in the industrial and other commercial activities, the vehicular traffic in the city is growing tremendously. Most importantly, besides national highway, there are four major arteriesviz state highway MDR that terminates into the heart of the city. All these roads bring in heavy amount of traffic partly designed to city and mostly to various parts ofthe state through the city via national highway. Though traffic mixes with the city to add its already existing traffic, moves out through narrow streets/roads of city to add to its already existing traffic woes and bottlenecks at various junction and a level crossing. The slow development of transportation facilities such as ring roads, internal roads as compared to the development of the city as a whole city is facing tremendous setback. Thus in the view of the ever increasing traffic needs of this high density corridors steps are being taken to improve traffic condition and to provide better connectivity. To solve the traffic problems including removing bottlenecks in the city, anintegrated road development program me has been formed. As funds are limited with this municipal corporation, it decided to implement this project through BOT.

BOTmechanism plays a vital role in the infrastructural development by

- Reducing financial burden on the Government.

- Assisting completion of the project in time.

- Enhances service quality and efficiency.

- Delivering better value of money proposition.

- Transparency and impartiality in the process of inviting private participation.

- Sharing the risks between Government and contractors.

- Improper decision making

- Negligence towards risks 
- Misinterpretation by users

- Political influence

\section{Objectives andData Collection Techniques}

The main objective of this paper is to examine the risk in BOT in post completionperiodi.e.Operation and maintenance period due to social oppose and political pressure.

\section{Need ofthe Project}

The IRDPprogramme was implemented to this particular city as this city has,

- Narrow Right Of Way

- $\quad$ Lack Of Public Transport

- Mixed Traffic Condition

- Encroachment

- Intersection Geometrics

- Enormous Increase In Vehicular Traffic

- Increase In Travel Time

- Increase In Traffic Congestion

- Increase In Pollution

- Increase in No. Of Accidents

\section{Objective of the Project}

- To develop and establish main road network in city.

- Development of entrance and link routes

- Widen and develop full road to dp width

- Provide storm water drain

- Provide central divider and footpath

- Improvement of junctionsprovide advanced street light illumination

- Facilitate beautification of road to enhance aesthetics of roads

- Provide urban infrastructure and road furniture

\subsection{General Data}

\section{Salient Featuresof the Project}

\section{Construction of integrated road development program me (IRDP) in the city on BOT basis.}

Name of client

Name of fascilitator

Name of the Company

Type of contract

Estimated cost of project

Date of work order

Duration of project

Concession period

Total km. to be executed

No. of Toll plaza

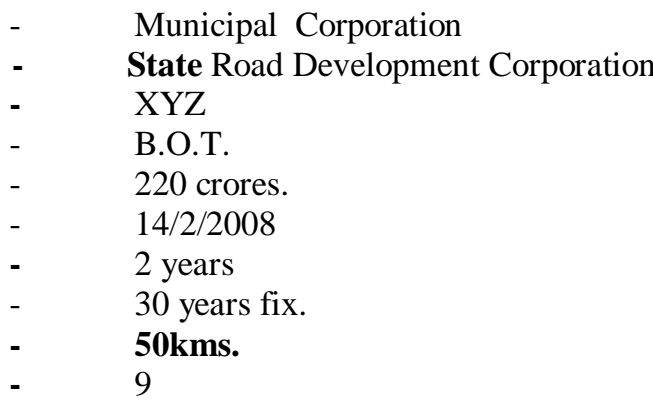

\section{Road Inventory}

The total project roads are classified into three categories namely External Routes (ER), Internal Routes(ER), and Link Routes (LR).Out of the total project $49.99 \mathrm{~km}$ road length of the road,External Routes are amounting to $30.79 \mathrm{~km}$. Internal Routes 5.6kmand remaining 12.60kmare Link Routes.

The DPplan width wise breakup of the total project roads is $3.5 \mathrm{~km}$ roads of $15 \mathrm{~m}$. DP width. $19.07 \mathrm{~km}$. roads of $18 \mathrm{~m}$. DP width $7.20 \mathrm{~km}$ roads of $24 \mathrm{~m}$. DP width and the balance $20.22 \mathrm{~km}$ roads are with $30 \mathrm{~m}$.DP width.

The scope of work on various roads in the project, with tentative costing for guidance of bidder is given below: 
Table A1 List of Project Roads,Toll Station\&ROB

\begin{tabular}{|c|c|c|c|}
\hline Road No. & Tentativeroad length & Proposed DP & Tentative cost in lacs \\
\hline ER1 & 8.3 & $30 / 18 / 15$ & 2951.11 \\
\hline ER2A & 3.8 & $30 / 24 / 15$ & \multirow[t]{3}{*}{2518.81} \\
\hline ER2B & 1.9 & $24 / 18 / 12$ & \\
\hline ER2C & 1.00 & $24 / 15 / 18$ & \\
\hline ER2D & 3.22 & 30 & \multirow[t]{2}{*}{2385.65} \\
\hline ER2E & 3.00 & $30 / 24$ & \\
\hline ER2F & 2.97 & 18 & 921.19 \\
\hline ER2G & 5.40 & $30 / 24 / 18$ & 1951.96 \\
\hline ER2H & 2.2 & 24 & 764.65 \\
\hline IR1 & 4.3 & 30 & 1762.38 \\
\hline IR2 & 1.3 & 18 & 381.09 \\
\hline LR1 & 3.4 & 18 & 999.17 \\
\hline LR2 & 0.8 & 18 & 235.73 \\
\hline LR3 & 2.50 & 18 & 741.32 \\
\hline LR4 & 2.7 & $15 / 18$ & 815.22 \\
\hline LR5 & 3.2 & $18 / 24$ & 967.94 \\
\hline TOLL STATIONS & & & \\
\hline TS1 & & & \multirow[t]{7}{*}{280} \\
\hline TS2 & & & \\
\hline TS3 & & & \\
\hline TS4 & & & \\
\hline TS5 & & & \\
\hline TS6 & & & \\
\hline TS7 & & & \\
\hline \multirow[t]{4}{*}{$\begin{array}{c}\text { RAILWAY OVER } \\
\text { BRIDGE } \\
\end{array}$} & & & 1369.21 \\
\hline & TOTAL & & 19009.43 \\
\hline & $\begin{array}{c}\text { CONTINGENCY } \\
\text { AT } 2.5 \%\end{array}$ & & 475.23 \\
\hline & GRAND TOTAL & & 19484.66 \\
\hline
\end{tabular}

Note 1: Approval of GAD of ROB shall be procured by the Concessionaire, State Road Development Corporation will give assistance in this matter

Note 2: Payment to railway authorities will be made by, State Road Development Corporation.

Note 3:Design of ROB will be made byconcessionaire at his own cost .Proof checking of railway portion of ROB by department and railway authorities. Also Proof checking of non-railway portion of ROB by the consultants appointed by the, State Road Development Corporationand the responsibility will be that of concessionaire

\section{Proposals}

- State Road Development Corporation - Facilitator

- Bot Operator--- Executing Agency

- Land Acquisition To Be Dealt By Municipal Corporation Before Work Order

- Shifting Of Utilities Is To Be Dealt By Bot Operator

- Encroachment To Be Removed By Municipal Commissioner

- Local Technical Assistance By The Municipal Corporation

- Exemption In The Octroi For The Material To Be Used For The Project

- Sources Of Revenue To Bot Operator

- Toll

- Advertisement Revenue

- Utility Rentals

- Plot Measuring 30000sq.M Given For Development On 99 Years Lease

- Commercial Exploitation Of Toll Station Area

VIII. Technical CriteriaforBidders

- Bidders /Consortium should have completed one bridge/flyover//rob costing Rs.7 crores

- Completed 4 lane road of min $15 \mathrm{~km}$. or 2 lane road min $25 \mathrm{~km}$

- Consortium should have built min $5 \mathrm{~km}$ road in corporation limit

- Company or consortium should have experience of bot project 
- Completed works of bridge /flyover//rob should be in the year

- Min Annual Turnover 1600 Million

\section{Financial CriteriaforBidders}

- Net Worth 60 Million

- Net Profit After Tax 100million

- Bid Capacity Min 2000 Million

- Min Equity 51\%

\section{Bid Evaluation}

- Bid will be evaluated as regards to responsiveness to technical data

- Bid passing the criteria will be considered for financial evaluation

- Concession period is fixed and concessionaire will quote on min viable gap funding

- State road development corporation will carry out confirmatory evaluation and issue loan to successful bidder

\section{Toll Collection}

Table A2Toll Rates

\begin{tabular}{|c|c|}
\hline Cars Goods Carrier, Auto & 15 \\
\hline Six Seator Auto & 15 \\
\hline LCV & 20 \\
\hline Bus & 35 \\
\hline Truck & 35 \\
\hline Multi Axle Vehicle & 40 \\
\hline
\end{tabular}

Note1:Nine Toll Stations are proposed

Note 2:25\% Concession for purchase of 50Coupons

Note 3:50\% Concession for purchase of 100 Coupons

Note 4:Single toll will be charged if vehicle passes same or other toll station within 6 hours.

Note 5:For monthly pass holders, $50 \%$ of monthly single journey charges.

Note 6:Toll rates are revised after every 3 third years with a growth rate of $6 \%$ per annum rounded

tonearestRs.5

\section{Expressionof Interest}

Municipal Corporation through state road development corporation will invited offer of interest to implement IRDP on BOT basis

The project involves construction and maintenance of road and ROB including land acquisitionfor the development of road and ROB along with shifting of utilities, landscaping, street lighting, construction and operation of toll stations etc.

\section{SalientFeatures of a Typical Concession Agreement (CA)}

This agreement is TRI PARTY AGREEMENT entered between, State Road Development Corporation Limited, City Municipal Corporation, And Entrepreneur Developing Integrated Road Development Program me.

$>$ The government has entrusted the state road development corporation, the implementation of IRDPon BOT basis.

$>$ State Road Development Corporation and the confirming party entered into the agreement to implement the said project as per mutually agreed revised scheme and has been approved by the confirming party.

$>$ The obligation to the state road development corporation and the confirming party and the funding arrangements of the said project are elaborated in the said agreement.

$>$ The confirming party in the said agreement has agreed and undertaken to discharge financial liabilities, if any arising for any reason whatsoever out of the concession agreement for implementation of the said project and to compensate and reimburse all costs and liabilities.

> State Road Development Corporation had resolved to implement approx... $50 \mathrm{Km}$. of roads in the city on build, operate and transfer basis .On terms and condition set forth in a CA. 
> State Road Development Corporation had act accordingly invited application for pre- qualification by its PQ notice for short listing of bidders for Design Construction, Operation and Maintenance of the project on BOT basis However State Road Development Corporation later decided to go in for post qualification.

$>$ State Road Development Corporation had prescribed the technical and commercial terms and conditions and invited bids from bidders pursuant to the tender notice for undertaking the projects.

$>$ After evaluation of the bids received, State Road Development Corporation had accepted the bod of the consortium and issued letter of acceptance to the consortium requiring interlaid, the execution of this Concession agreement within 30 days of issue thereof.

$>$ Theconsortium has sincepromoted and incorporated a limited liability company under the companies act 1956 and requested State Road Development Corporation to accept the concessionaire as the entity which shall undertake and perform the obligation and exercise the right of the consortium under the LOA including theobligation to enter into concession agreement pursuant to the LOA for executing the project.

$>$ By its letter, the concessionaire has also joined in the said agreement of the consortium to State Road Development Corporation to accept it's as the entity which shall undertake and perform the obligation and exercise the right of the consortium under the LOA including theobligation to enter into concession agreement pursuant to the LOA for executing the project.

$>$ State Road Development Corporation had agreed to the said request of the concessionaire and has accordingly agreed to enter into this concession agreement with the concessionaire for execution of the project on BOT basis, subject to and on the terms and conditions set forth hereinafter.

\section{Scope Of Work For Widening And Improvement Of TheRoad Projects}

\begin{tabular}{|c|c|c|c|}
\hline Sr.No. & Description Of Item & Tentative Quantity & Unit \\
\hline 1 & Survey,Investigation, Design & 49.99 & KM. \\
\hline \multirow[t]{5}{*}{2} & Improvement By Strengthening And Widening & & \\
\hline & A)B.T. Treatment For Existing 15 M DP Roads & 3.5 & KM. \\
\hline & B)B.T. Treatment For Existing 18 M DP Roads & 19.07 & KM. \\
\hline & C)B.T. Treatment For Existing 24 M DP Roads & 7.20 & KM. \\
\hline & D)B.T. Treatment For Existing 30M DP Roads & 20.22 & KM. \\
\hline 3 & Widening Of Cd Works And/Slab Drain & 54 & NO. \\
\hline 4 & Widening Of Minor Bridge & 8 & NO. \\
\hline 5 & Widening Of Major Bridge & 1 & NO. \\
\hline 6 & Rob New Bridge & 1 & NO. \\
\hline 7 & Toll Plaza & 7 & NO. \\
\hline 8 & Junction Improvement & 18 & NO. \\
\hline 9 & $\begin{array}{l}\text { Traffic Sign ,Road Markings, And Appurtances, Median } \\
\text { Verge, Kerb Stone } \\
\text { Gantries - } 18 \\
\text { Informatory-110 } \\
\text { Cautionary- } 73 \\
\text { Slogans- } 46 \\
\end{array}$ & 49.99 & KM \\
\hline 10 & Raising Of Foot Paths Median Verge \& Gutters & 99.98 & KM \\
\hline 11 & Development Of Major Junction & 55 & NO. \\
\hline 12 & Sculptures In Traffic Island With Decorative Railing & 10 & NOS \\
\hline 13 & Seat Outs & 130 & NOS \\
\hline 14 & Provision Of Decorative Lamps In Garden & 75 & NOS \\
\hline 15 & Carpet Lawn & 2000 & SQ.M \\
\hline 16 & High Mast Lamps & 16 & NOS. \\
\hline 17 & Dust Bins & 29 & NOS \\
\hline 18 & Tree Guards & 1500 & NOS \\
\hline 19 & Crash Barriers & 500 & NOS. \\
\hline 20 & Bus Shelters & 19 & NOS \\
\hline 21 & Ducts & 99.98 & KM. \\
\hline 22 & Plantation & 82.137 & NO \\
\hline 23 & Landscaping Of Spots Identified By State Authorities & 5 & NO. \\
\hline
\end{tabular}

\section{Traffic Study and Analysis}

\begin{tabular}{|c|c|c|c|c|c|c|c|c|}
\hline $\begin{array}{l}\text { TollPlaza } \\
\text { Location }\end{array}$ & $\begin{array}{l}\text { Car/Jeep/V } \\
\text { an/6s/Auto }\end{array}$ & LCV & $\begin{array}{l}\text { S T } \\
\text { Bus }\end{array}$ & $\begin{array}{l}\text { Other B } \\
\text { us }\end{array}$ & Truck & MAV & $\begin{array}{l}\text { Tracto } \\
\text { r }\end{array}$ & Total \\
\hline Shahu & 3888 & 290 & 715 & 153 & 541 & 9 & 20 & 5615 \\
\hline Uchgaon & 3859 & 309 & 286 & 16 & 437 & 3 & 65 & 4975 \\
\hline Washi & 1730 & 177 & 346 & 44 & 462 & 1 & 82 & 2841 \\
\hline Shiye & 1568 & 177 & 90 & 14 & 432 & 1 & 115 & 2398 \\
\hline Fulewadi & 2077 & 379 & 569 & 96 & 931 & 5 & 213 & 4271 \\
\hline Kalamba & 887 & 152 & 200 & 17 & 283 & 5 & 25 & 1567 \\
\hline Shiroli & 11159 & 1191 & 2355 & 523 & 2655 & 16 & 72 & 17972 \\
\hline
\end{tabular}


Mode wise Distribution of the Traffic
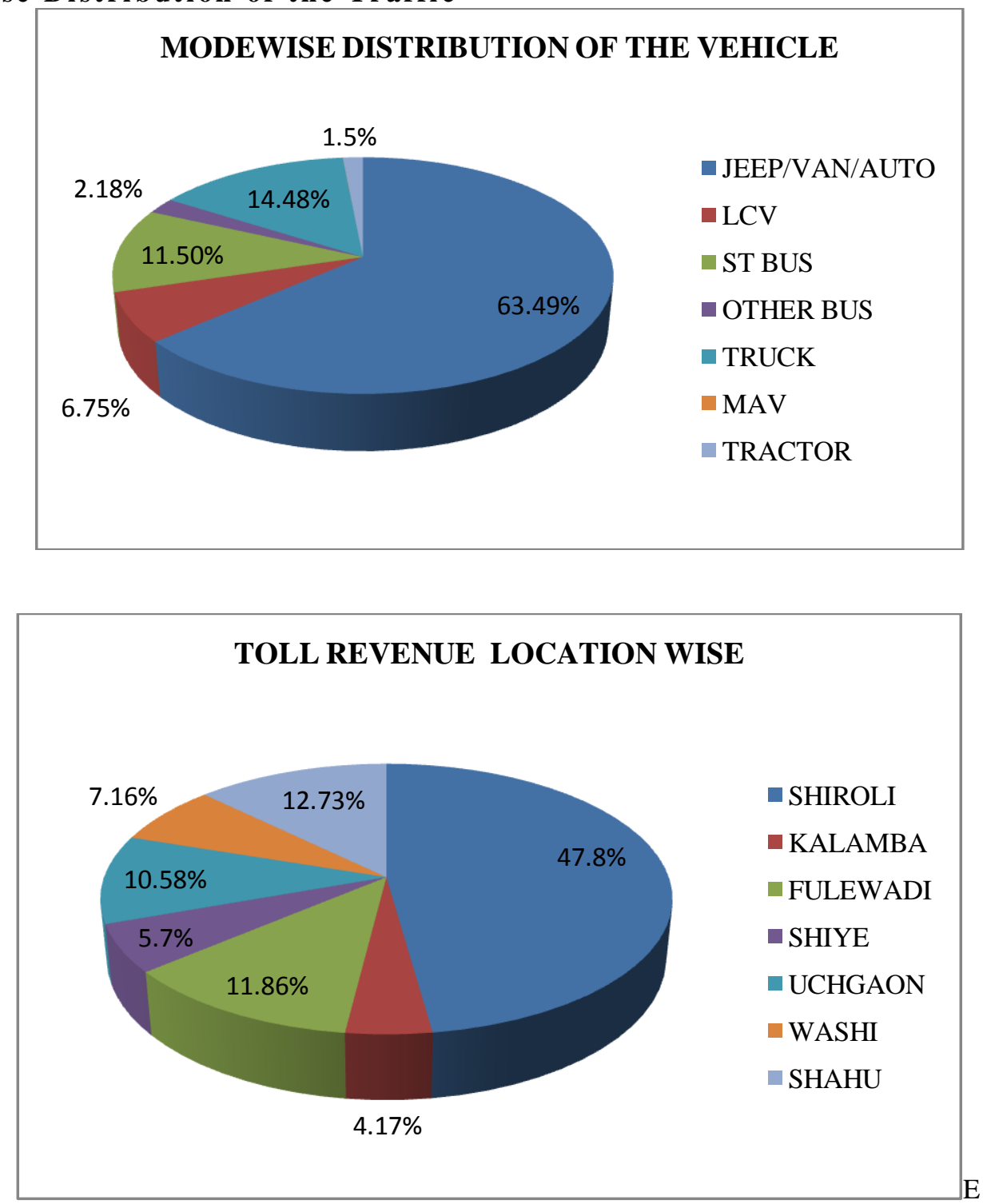

XVI. Toll Exempted Vehicles

* State MLA'S /MP's Vehicles

* Central And State Government Vehicles

* Police Vehicles

* Military Vehicles

* Post And Telegraph Department Vehicles

* Ambulances

* Fire Brigade Vehicles

* Hearse

* Empty Tractor With Trailor

* KMT buses

* Two Wheeler/ Three Wheeler /Auto

X V II. Risks Faced By Contractor

17.1 Social Risk: Social risk is defined as unexpected risk caused by social, cultural habit and costume of the host country \& local community. Five factors have been identified.

1) Strike of workforce or union

2) Publicdiscrimination

3) Ethical or religious strike

4) Different working conditions such as language, climate, weather 
5) Dishonesty or bribe

Work of IRDP is completed in all respect by the concessionaire in Dec 2011.

Due to continuous oppose to tolling a private infrastructure firm is waiting for revenue.

Compensation towards loss of toll caused by toll stoppage from 01.08.11- tilldate.

Tired of waiting for the state government to act and alarmed at its rising interest costs, a private infrastructure firm has served a notice to the Municipal Corporation) and State Road Development Corporation) to allow it to collect toll for a unique city road project and also sought compensation for losses.

The company, built a 50-km, 13-road project in city under the integrated road development project, the first of its kind in the state which envisaged collecting tolls on roads within the city. Some of the 13 roads had four lanes and the others six, and covered about $50 \mathrm{~km}$. The project cost about Rs 420 crore and was completed in August 2011.

The state government allowed company to collect toll through a December 17, 2011 notification. But exactly a month later, it was asked to stop collecting toll. While state government agencies claim that the quality of company's work is deficient, some state and company's officials privately say that the government's hand was forced by opposition to toll by local politicians.

With interest costs alone touching Rs 40 crore, company's served a notice to the two bodies on January 23, demanding the toll suspension notice be lifted and compensation for losses incurred over the last one year as the roads are being used since their completion in 2011. A copy of the notice has also been sent to the chief minister, the deputy chief minister, the chief secretary and secretaries of the urban development and public works departments.

Company chairman and managing director said the company is also contemplating going to court seeking permission to collect toll as per its agreement with the state government.

\section{Conclusion}

Effective communication to the project to various stake holders and large public support is the key lesson Absence of support from public at large can lead to many hurdles at any stage of the project in land acquisition stage displacement of people and in operation stage oppose to collection of revenue in the form of toll tariff

Public support is crucial in project siting decisions.Public support no matter is important strong political will is also important to make the project happenLarge path breaking projects are required active hand holding from government throughout the project life cycleInspite of completion of the IRDP project successfully due to social and political problems company is facing problems in collection of toll. .Notification for toll collection was issued in Dec 2011 and stoppage of toll collection notice issued in January 2012.

\begin{tabular}{|l|l|l|l|l|}
\hline $\begin{array}{l}\text { Social } \\
\text { risk }\end{array}$ & $\begin{array}{l}\text { Throughou } \\
\mathrm{t} \text { Project } \\
\text { Cycle }\end{array}$ & $\begin{array}{l}\text { This is a risk that civil/political problems may surface as a result of } \\
\text { project, manifesting in boycotts, sabotage etc. Such disturbances may } \\
\text { arrive from a number of different concerns, public objection to } \\
\text { imposition of tariff public discontent with the environmental impact of } \\
\text { civil work or other features of the project an event similar to any of } \\
\text { above could impair the ability of the concessionaire to collect revenue } \\
\text { project } \\
\text { thereby affecting project viability. }\end{array}$ & $\begin{array}{l}\text { poved } \\
\text { provides } \\
\text { cover against the } \\
\text { risks. }\end{array}$ \\
\hline
\end{tabular}

\section{References}

[1] Tender Document ForIRDP Project

[2] P.W.D. Government of Maharashtra, 1978 - 2005,Compendium of Govt / circulars Standard instructions regarding privatization of works of 'Road, Bridges, Building.

Authors Bio Data:

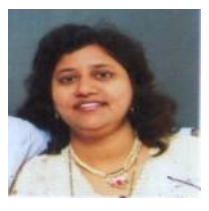

Rinaj M. Pathan obtained bachelor of engineering in Civil from ShivajiUniversity, Kolhapur in Maharashtra in 1994. She has been selected as Class I Officer in Engineering MPSC. Since last two years She is a student of the post graduate programme at construction and management, Dept. Of Civil Engineering, Maharashtra institute of technology, Pune, India.

Her research interest is in construction materialtesting, infrastructuraldevelopment,BOT\& project management.

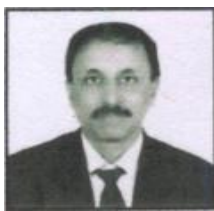

Dr. S. S. Pimplikar is presently professor \& head of the Department of Civil Engineering, Maharashtra Institute of Technology, Pune, India.

His subject areas in which he is teaching are: project management, new construction materials, accident studies, statistical methods, estimation \& tendering \& financial management.

His research interest is in construction material, transport engineering, green building and project management. Presented papers in international conferences and publish technical papers is a member of the Indian road congress, Indian society of hydraulics\& Indian society of technical Education. 